\title{
STRATEGI PENYEBARLUASAN ILMU HUKUM MELALUI SASTRA
}

\author{
Murti Ayu Hapsari \\ Universitas Janabadra, Yogyakarta, Indonesia \\ Email: murtiayu@janabadra.ac.id \\ Murtini \\ Universitas Sebelas Maret, Surakarta, Indonesia \\ Email: murtini@staff.uns.ac.id
}

\author{
Article history: \\ Submitted Sept 03, 2020 \\ Revised Oct 13, 2020 \\ Accepted Aug 26, 2021 \\ Published Dec 03, 2021
}

\begin{abstract}
Novels are one of the literary genres that utilize language. In this case, the use of language in literary or literature, according to Umar Kayam, is not about using it correctly or not, but rather whether or not that language appropriate for specific occasion. Likewise, legal science cannot separate itself from language in terms of its application. Language in law of legal filed has its own variety which often makes it difficult for people who are not directly involved in it to grasp its certain meanings. This is because language in law require that it can conveyed in a concrete, straightforward manner, so that it will not lead to many ambiguous interpretations. It can be said that the use of language form in these two domains is in very opposite direction. Novel written by Agus Sardjono, "Legal Research: A Novel on Legal Research Methods" tries to unravel these difficulties by using literary as tools specifically to facilitate students of university in understanding and applying legal research methods. This paper will further describe the novel in two perspectives; legal point of view and literary point of view. The novel "Legal Research" proves that literature is a very broad as a medium, that can be used to describe various field of expertise such as history, psychology, politics, including law.
\end{abstract}

Keywords: law novel; legal science; literary art; novel 


\begin{abstract}
ABSTRAK
Novel merupakan salah satu genre sastra yang mendayagunakan bahasa. Dalam hal ini, penggunaan bahasa dalam sastra, menurut Umar Kayam, bukanlah menuntun penggunaan bahasa Indonesia yang baik dan benar, melainkan bahasa yang pas. Demikian pula dengan ilmu hukum yang tidak dapat melepaskan diri dari bahasa sebagai sarana penyampaiannya. bahasa dalam ilmu hukum memiliki ragam tersendiri yang kerap membuat orang yang tidak secara langsung terjun di dalamnya kesulitan untuk menangkap makna tertentu dalam kalimat-kalimatnya. hal ini dikarenakan bahasa dalam hukum menuntut suatu hal disampaikan secara konkrit, lugas, sehingga tidak akan menimbulkan penafsiran baru. Penggunaan bahasa dalam dua ranah ini dapat dikatakan merupakan dua hal yang sangat berseberangan. Novel yang ditulis oleh Agus Sardjono berjudul Riset Hukum: Sebuah Novel tentang Metode Penelitian Hukum berusaha mengurai kesulitan tersebut dengan menggunakan sarana sastra dikhususkan untuk memudahkan mahasiswa dalam memahami dan mengaplikasikan metode penelitian hukum. Tulisan ini akan menjabarkan lebih lanjut novel tersebut dalam dua sudut pandang; sudut pandang hukum dan sudut pandang sastra. Novel Riset Hukum membuktikan bahwa sastra merupakan wadah yang luas, yang mana dapat diisi bermacam persoalan seperti sejarah, psikologi, politik, termasuk ilmu hukum.
\end{abstract}

Kata kunci: novel hukum; ilmu hukum; sastra; novel

\title{
PENDAHULUAN
}

Ilmu pengetahuan tidak harus diperoleh dengan cara mengerut dahi. Ia juga dapat diperoleh melalui diskusi ringan di antara para sahabat. Ilmu pengetahuan hanya membutuhkan keseriusan kita dalam mencari, karena ia ada di mana-mana. Ia juga bisaada di dalam sebuah novel, seperti yang ada digenggaman Anda saat ini (Sardjono, 2019). Pernyataan ini diungkapkan oleh Prof. Dr. Agus Sardjono seorang guru besar dari Fakultas Hukum Universitas Indonesia, sebagai prolog untuk novelnya berjudul Riset Hukum: Sebuah Novel Tentang Metode Penelitian Hukum yang diterbitkan oleh Murai Kencana PT RajaGrafido Persada Depok tahun 2019.

Berdasarkan penelusuran peneliti, Prof. Dr. Agus Sardjono, S.H., M.H., (selanjutnya Agus Sardjono), sebagai akademisi memang banyak menghasilkan tulisan, kebanyakan karya ilmiah. Riset Hukum merupakan novel pertamanya. Karya ini sebagai untuk menjabarkan metode penelitian hukum agar lebih mudah 
dipahami oleh pembaca (terutama mahasiswa Fakultas Hukum). Dalam kancah sastra ditemukan data, beliau dikenal juga sebagai pencipta lagu dan musisi. Hal inilah yang menjadikan Agus Sardjono diangkat sebagai Ketua Divisi Hukum “Persatuan Artis Penyanyi, Pencipta Lagu dan Pemusik Republik Indonesia (PAPPRI) tahun 2012-sekarang.

Novel merupakan salah satu genre sastra. Sepeti diungkapkan Culler (1975), sastra merupakan seni yang mendayagunakan bahasa. Demikian juga ilmu hukum juga tidak bisa melepaskan diri dari bahasa sebagai sarana penyampaiannya, dan keduanya memiliki gaya yang berbeda dalam penyampaian. Berkenaan dengan bahasa Umar Kayam (1987) mengatakan, penggunaan bahasa dalam sastra yang penting bukan masalah bahasa Indonesia yang baik dan benar, melainkan bahasa yang pas.

Riset Hukum merupakan novel yang mengisahkan persahabatan 6 mahasiswa Fakultas Hukum Universitas Indonesia. Dalam novel ini memang tampaknya yang ditonjokan oleh Agus Sardjono, tentang metode penelitian hukumyang muncul dalam diskusi-diskusi dan dialog-dialog oleh 6 mahasiswa (Anggi, Kaka, Santi, Olive, Gendis, Tobi) ditambah tokoh Pak Brata sebagai dosen metode penelitian hukum.

Persoalan hukum yang rumit dan kompleks sengaja "dicaitkan" oleh Agus Sardjono melalui ranah sastra, yakni novel. Seperti diungkapkan Horace sastra merupakan tulisan yang bersifat dulce et utile (menyenangkan dan berguna). Selanjutnya Koestler menegaskan penulis yang baik adalahpenulis yang dalam tulisannya selalu berusaha bercerita mencoba memberi tafsiran yang jujur dan pada tempatnya tentang kehidupan dengan segala ragam persoalannya (Kayam, 1982)

Berdasarkan uraian di atas masalah yang timbul dalam penelitian ini adalah, sejauhmana ranah sastra (dalah hal ini novel) mampu didayagunakan dalam upaya penyebaran ilmu hukum. Adapun tujuan penelitian ini adalah untuk mengetahui dan menemukan pendayagunaan sastra dalam ilmu hukum. 


\section{TEORI DAN METODE PENELITIAN}

Penelitian ini akan menggunakan teori structural Tzvetan Todorov. Esensi dasar teori structural, bahwa karya sastra terdiri dari unsur-unsur untuk membangun satu kesatuan. Adapun menurut Todorov (Todorov, 1985) jenis hubungan antara unsur-unsur itu jumlahnya tak terhingga. Namun, terdapat 2 kelompokbesar: hubungan antar unsur yang hadir bersama, in praesentia, dan hubungan antara unsuryang hadir dan tidak hadir, in absentia. Hubunganhubungan itu membedakan pula hakikatmaupun fungsinya.

Dalam pada itu, sastra bukan suatu sistem lambang primer (seperti seni lukis, bahasa, misalnya dapat menjadi sistem lambang primer), tetapi sebagai sistem lambang sekunder karenasebagai materi dasar sastramempergunakan sistem yang sudah ada, yaitu bahasa (Todorov, 1985).

Selanjutnya Todorov (Todorov, 1985) mengatakan, untuk memaknai karya sastraterdapat 3 tahap yang harus dilalui yaitu: aspek sintaksis, aspek semantic, dan aspek verbal. Aspek sintaksis untuk meneliti pengaluran atau urutan peristiwa secara kronologis. Aspek semantic menitikberatkan pada tema, tokoh, dan latar. Sementara itu aspek verbal meliputi: sudut pandang, gaya atau pengujaran. Dalam penelitian ini pembahasan sastra dititikberatkan pada: pengaluran (aspek sintaksis), tema dan tokoh (aspek semantik), gaya (aspek verbal).

Kajian ini digunakan metode kualitatif deskriptif. Metode ini merupakan suatu cara untuk menggali objek penelitian melalui data berupa novel yang berjudul Riset Hukum: Sebuah Novel Tentang Metode Penelitian Hukum, menganalisis, dan mendeskripsikan secara sistematis, faktual dan akurat mengenai fakta-fakta dan sifat-sifat populasinya (Dirjen Dikti, 1981). Objek material penelitian ini adalah novel Riset Hukum karya Agus Sardjono, sedangkan objek formal adalah sejauh mana novel ini mampu sebagai sarana penyebarluasan ilmu hukum. 


\section{HASIL DAN PEMBAHASAN}

\section{Sudut Pandang Hukum}

Buku ini terdiri dari tiga bab yang kesemuanya saling berkaitan sebagai satu kesatuan dalam pembahasan metode penelitian dalam ilmu hukum; bab-bab tersebut tercakup dalam; a) Hukum sebagai Objek Penelitian, b) Metode Penelitian Hukum, c) dan Menulis Laporan Penelitian Hukum. Tulisan ini akan membahas lebih jauh bagaimana ketiga bab tersebut mengelaborasikan permasalahanpermasalahan yang kerap dihadapi mahasiswa hukum, pada khususnya, dalam melakukan awalan penelitian, proses penelitian, hingga penulisan laporan penelitian itu sendiri. Dengan menggunakan sistematika dalam buku ini, permasalahanpermasalahan tersebut antara lain adalah:

a) Hukum sebagai Objek Penelitian

Pembahasan dalam bab ini difokuskan pada bentuk hukum - atau hakikat hukum dalam berbagai bentuk dan pengertiannya. Bab ini mengajak pembaca untuk lebih mengenal atau terjun lebih dalam terkait apa itu hukum dengan menyajikan pengertian-pengertian hukum dari pendapat berbagai ahli yang memiliki latar belakang aliran hukum yang berbeda-beda. Berbagai pengertian hukum tersebut kemudian dielaborasikan dalam ciri-ciri khusus hukum untuk dapat memberikan pemahaman lebih mendalam terkait ilmu hukum dengan cabang ilmu sosial lainnya. Pembaca dalam hal ini juga diberikan pengertian bahwa hukum, meskipun entitas yang sangat identik dengan nilai, tidak dapat sepenuhnya steril dari kenyataankenyataan sosial, politik, ekonomi, dan budaya.

Lebih lanjut untuk dapat menentukan objek dalam penelitian hukum, hal utama dan pertama yang harus dilakukan adalah mengenali ciri ilmu hukum (dogmatik hukum), teori hukum, dan filsafat hukum (Sardjono, 2019) yang merupakan bagian dari teori lapisan ilmu hukum. Secara kronologis, perkembangan ilmu hukum diawali oleh filsafat dan disusul dogmatik hukum. Kedua disiplin tersebut memiliki perbedaan yang sangat ekstrim, yang mana filsafat hukum bersifat sangat spekulatif, sedangkan dogmatik hukum bersifat sangat teknis. Diantara keduanya terdapat teori hukum/ajaran hukum umum yang berfungsi untuk 
menjembatani filsafat hukum dengan dogmatik hukum (Hadjon dan Tatiek Sri Djatmiati, 2020). Meskipun dalam perkembangannya pembedaan terhadap ketiganya dianggap kurang begitu penting oleh karena hanya akan memperlambat perkembangan dari ilmu hukum itu sendiri. Meskipun demikian, sejalan dengan teori tersebut, dinyatakan bahwa penelitian hukum dilakukan dalam rangka untuk memberikan kontribusi bagi perkembangan teori hukum dan ilmu hukum; di mana terungkapnya law in the book (aturan yang seharusnya) dan law action (penerapan hukum). Dengan demikian dalam penelitian ilmu hukum terdapat dua jenis penelitian; a) penelitian dengan objek norma hukum, dan b) penelitian dengan objek empiris hukum (Sardjono, 2019).

Penelitian norma hukum (biasa disebut dengan penelitian hukum normatif) adalah penelitian yang dilakukan dengan objek aturan perundang-undangan yang dikeluarkan oleh Pemerintah dalam rangka menyelenggarakan pemerintahan negara. Sedangkan penelitian empiris hukum merupakan penelitian hukum yang menitikberatkan pada penerapan hukum di tengah masyarakat. Pembedaaan ini tidak memiliki makna yang hierarkhis, artinya tidak ada jenis penelitian hukum yang "kedudukannya" lebih tinggi daripada jenis penelitian hukum yang lain (Hadjon dan Tatiek Sri Djatmiati, 2020). Pembedaaan dari kedua jenis penelitian ini sebatas memberikan konsekuensi logis bahwa nantinya akan ada pembedaan pula dalam merumuskan metode penelitian sebagai pisau analisis.

Dalam buku ini juga dikutipkan pendapat yang masih sering menjadi perdebatan dalam akademisi hukum sampai sekarang dalam kuliah-kuliah metode penelitian hukum yaitu pendapat yang dinyatakan oleh Peter Mahmud yang menyatakan bahwa penelitian hukum empiris bukan merupakan bagian dari penelitian hukum, namun merupakan penelitian sosial biasa oleh karena objek penelitiannya adalah gejala sosial, bukan norma sosial. Pendapat ini dimunculkan untuk lebih menekankan bahwa perbedaan pendapat dan perbedabatan hukum, yang dalam hal ini dituangkan dalam bentuk penelitian hukum, menjadi tulang punggung perkembangan ilmu hukum ataupun praktik hukum dan menjadi bagian yang tidak terpisah dari ilmu hukum itu sendiri, apapun nama atau metode yang 
digunakan (Peter Mahmud dalam Sardjono, 2019). Hal terpenting bagi peneliti hukum adalah tujuan penelitian serta konsistensi dalam menerapkan nalar berpikir dan berargumentasi.

b) Metode Penelitian Hukum

Bab ini sedikit banyak masih menyinggung terkait pembedaan antara penelitian hukum normatif dengan penelitian hukum empiris pada bab sebelumnya. Berdasarkan narasi yang ditawarkan, penulis buku memberikan pendapat bahwa pembedaan tersebut akan membuat ilmu hukum menjadi tidak seimbang dan terbatas. Penulis buku berpendapat bahwa untuk benar-benar memahami dan menemukan jawaban dari proses penelitian hukum, peneliti tidak mungkin hanya meneliti pasal-pasal undang-undangnya saja, namun juga harus meneliti keadaan yang senyatanya terjadi di lapangan (Sardjono, 2019). Konsekuensi dari pembedaan jenis penelitian hukum ini terletak pada metode penelitian yang nantinya akan diterapkan. Metode penelitian hukum sangat ditentukan oleh pokok permasalahan yang hendak dicari jawabannya melalui penelitian tersebut; ketika penelitian bersifat normatif maka metodenya akan berbeda dengan penelitian hukum empiris, begitu pula dengan jenis data, cara mengumpulkan data serta prosedur penelitiannya (Sardjono, 2019).

Tidak jarang ada peneliti yang menyatakan bahwa baik metode penelitian hukum normatif dan metode penelitian hukum empiris dapat berjalan beriringan sesuai dengan tujuan serta esensi dari penelitian hukum tersebut diselenggarakan. Esensi dari penelitian hukum, diantaranya adalah: 1) berangkat dari kasus yang faktual yang mengandung fakta hukum (yang nantinya bisa diangkat menjadi objek penelitian), 2) bahan-bahan yang mudah diakses, 3) menentukan teori yang tepat sebagai pisau analisis. Kesemuanya merupakan hal yang esensial dari penelitian hukum ditambah dengan kemampuan peneliti untuk mengolah, berargumen, dan menyusun narasi analisis penelitian. (Sardjono, 2019).

Pemaparan tersebut dapat dijelaskan bahwa dalam memulai suatu penelitian hukum, fakta yang menjadi dasar penelitian hukum haruslah fakta hukum yang benar-benar terjadi. Fakta hukum tersebut merupakan sebuah fenomena kompleks 
yang problematik sehingga perlu dicarikan penyelesaiannya dalam sebuah penelitian hukum. Dalam hal ini fakta hukum tidak terbatas pada "peristiwa aktual" namun juga dapat ditemukan dalam peraturan perundang-undangan yang mungkin substansinya kurang mencerminkan tujuan bernegara dalam Undang-Undang Negara Republik Indonesia Tahun 1945 (UUD NRI Tahun 1945). Sebagai contoh, dapat dilakukan penelitian dengan mengumpulkan peraturan perundang-undangan yang mengatur kegiatan dalam bidang ekonomi, kemudian dicari tahu apakah peraturan perundang-undangan tersebut telah berdasarkan falsafah ekonomi Pancasila dan UUD NRI Tahun 1945.

Analisis merupakan tahap akhir dari suatu penelitian dan dilakukan bersamaan dengan laporan penelitian. Dalam melakukan analisis, peneliti dituntut untuk melakukan pembahasan masalah hukum. Semakin lengkap dan luas bahan dan sumber yang digunakan oleh peneliti maka akan semakin meningkatkan kualitas dari tulisan tersebut. Hal lain seperti subjektivitas peneliti juga sangat menentukan kualitas hasil penelitiannya. Dapat disimpulkan bahwa kualitas suatu tulisan ditentukan dari dua faktor utama, yaitu: 1) data atau bahan yang dikumpulkan, dan 2) kemampuan peneliti dalam mengumpulkan data dan dalam menggunakan bahasa. Peneliti yang baik senantiasa cenderung mencari sumber dengan tingkat yang tinggi validitasnya, sehingga nantinya data yang terkumpul akan cukup untuk membangun argumentasi yang komprehensif.

Dalam penelitian hukum, khususnya penelitian hukum normatif, dikenal bahan hukum yang dibagi menjadi tiga. Ketiganya adalah bahan hukum primer, bahan hukum sekunder, dan bahan hukum tersier. Bahan hukum primer merupakan bahan hukum yang bersifat autoriatif (memiliki otoritas), bahan hukum ini terdiri dari perundang-undangan, catatan resmi, atau risalah dalam pemuatan perundangundangan yang relevan. Bahan hukum sekunder berupa semua publikasi tentang hukum yang bukan merupakan dokumen resmi, bahan hukum ini meliputi buku teks, kamus hukum, jurnal hukum, dan komentar atas putusan pengadilan yang relevan. Bahan hukum tersier merupakan bahan-bahan non-hukum yang dipandang perlu dan relevan, dalam hal ini bahan non-hukum dapat mencakup buku mengenai 
ilmu sosial-politik, ekonomi, filsafat, hingga budaya (Marzuki, 2011). Hal ini semakin menekankan pernyataan dalam bab sebelumnya yang menyatakan bahwa hukum merupakan entitas yang tidak dapat sepenuhnya steril dari kenyataan-kenyataan sosial, politik, ekonomi, dan budaya.

c) Menulis Laporan Penelitian Hukum

Dalam bab ini ditulis lebih rinci terkait teknis dalam menulis laporan penelitian hukum, mulai dari cara menentukan topik dan judul hinggi merumuskan simpulan penelitian. Dalam bab ini penulis memberikan penekanan bahwa penulisan ilmiah, secara khususnya penulisan hukum tidak seharusnya terpaku pada 'kaidah penyampaian' yang seolah-olah menentukan bahwa bahasa akademik harus "kering-kerontang" dan "steril dari gaya bahasa yang ringan dan komunikatif", untuk mendukung argumentasinya, penulis mencontohkan novelis seperti Pramooedya Ananta Toer, J.K. Rowling, Josh Grisham, serta Dan Brown. Poin penting dalam penulisan ilmiah adalah bagaimana mempertahankan seluruh isi tulisan dalam alur yang konsisten, fokus, dan tidak melebar ke sana kemari. Untuk dapat mengukur hal tersebut diperlukan pengecekan konsistensi antara theses statement (pernyataan awal), supporting details (argumentasi pendukung), dan conclusion (simpulan). Simpulan dalam hal ini, bukan hanya sekedar meringkas tulisan yang telah disusun, namun lebih kepada intisari dari analisis berdasarkan permasalahan yang ada. keseluruhan unsur-unsur tersebut harus ada benang merahnya.

\section{Sudut Pandang Sastra}

\section{a. Aspek Sintaksis}

Novel Riset Hukum terbitan Murai Kencana PT RajaGrafindo Persasa tahun 2019 terdiri atas 3 bab. Dengan penjabaran seperti buku teks, yakni BAB I berisi subbab Hukum Sebagai Objek Penelitian (ciri-ciri objektif dari hukum, hukum sebagai ilmu, ilmu hukum dan penelitian hukum). BAB II berisi subbab metode penelitian hukum (menemukan dan merumuskan masalah hukum, unsur esensial dari metode penelitian hukum, informasi atau data yang diperlukan dalam 
penelitian. BAB III berisi sub bab menulis laporan penelitian. Di samping itu terdapat halaman persembahan, prolog, epilog dan biodata penulis. Secara fisik daftar isi ini masih merpakan bentuk buku teks, namun di dalamnya berisiuraian persoalan hukumyang dihidupkan oleh tokoh-toh yang ada.

Novel setebal 294 halaman inimemaparkan peristiwa yang dominan yakni persoalan bagaimana memahami dan menerapkan metode penelitian hukum seperti yang diuraikan dalam analisis sudut pndang hukum di atas. Dalam pada itu pengaluran cenderung landau, artinya relative tidak ada penggambaran peristiwa yang mapu menggambarkan pergolakan jiwa tokoh-tokoh. Peristiwa yang ada selalu menggambarkan tokoh-tokoh (Gendis, Anggi, Olive, Kaka, Santi, Tobi)berdikusi tentang ilmu hukum.

Novel ini menggambarkan persahabatan keenam tokoh tersebut, yang selalu rukun, saling mendukung, relatif tidak ada konflik di antara mereka. Bahkan terdapat peristiwa yang menggambarkan persahabatan yang luar biasa. Yakni peristiwa tokoh Kaka (yang berasal dari keluarga kurang mampu, dan harus membiayai diri sendiri untuk kuliah), ketika mendapat bea siswa dan motor baru (hal 68-69). Untuk membiayai kulaih Kaka mncari uang sebagai tukang ojek. Adapun Anggiyang dikenal sebagai mahasiswa kaya, suka berderma, berusaha membujuk ayahnya agar perusahaannya berkenan memberi bea siswa kepada Kaka Kebaikan hati Anggi tidak hanya sampai di sini, saat Kaka ulang tahun, Anggi dibantu Olive memberi hadiah sepeda motor baru. Hal ini dilakukan karena kedua mahasiswa ini mengetahui motor Kaka (yang dipakai ngojek) sering mogok. Peristiwa lain yang menggambarkan kehebatan hati Anggi yang didukung Olive dan Gendis adalah merenovasi rumah keluarga Kaka (h. 283-294).

Selebihnya novel yang dijabarkan melalui 53 peristiwa atau sekuen ini mayoritas berisi diskusi tokoh-tokoh (akan diulas dalam aspek semantik) tentang ilmu hukum dengan menggunakan latar kampus, kantin (milik ibu Santi), taman, perpustakaan. 


\section{b. Aspek Semantik}

Seperti telah disinggung di atas, novel ini mengisahkan 6 mahasiswa yang berkuliah di Fakultas Hukum Universitas Indonesia. Mereka adalah Anggi, Gendis, Tobi, Kaka, Santi, Olive. Keenamnya digambarkan bersahabat, meskipun dengan latar belakang ekonomi yang berbeda-beda, dan juga karakter yang berbeda pula. Mengacu pendapat Kuntowijoyo (1984), sastra Indonesia tidak mempunyai tradisi psikologismeme yang kuat, dalam arti bahwa penokohan dan perwatakan dalam karya sastra tidak banyak mempersoalkan perkembangan personalitas dari pelakupelakunya. Tokoh-tokoh dalam sastra tidak mempunyai perwatakan yang merdeka, tetapi merupakan tokoh yang sudah ditertibkan. Jika hal ini benar, tradisi pewayangan masih kuat berakar dalam sastra modern kita. Sehingga imbangan dari ketiadaantradisi personalisme ini, sastra Indonesia mempunyai tradisi tipologisme. Dalam sastra tipologis para pelaku sudah mempunyai personalitas yang mapan, terbentuk sejak ia muncul.

Dalam novel Riset Hukum tokoh-tokoh digambarkan sebagai berikut.

a) Gendis: dari keluarga berada, baik hati, agak galak

b) Anggi: anak tunggal dari keluarga kaya raya, baik hati, dermawan

c) Olive: baik hati, dari keluarga mampu

d) Kaka: memiliki semangat belajar yang tinggi, dari keluarga kurang mampu

e) Santi: rajin, dari keluarga sederhana

f) Tobi: pacar Gendis, agak pendiam, baik hati

Keenam tokoh tersebut tampaknya digambarkan oleh Agus Sardjono sebagai penulis novel ini semenjak awal sampai akhir cerita, relative tidak mengalamipersoalan yang berarti. Hal ini terkait dengan pendapat Kuntowijoyo, tokoh sudah mempunyai personalitas yang mapan. Tokoh Anggi, Gendis, dan Olive yang berasal dari keluarga mampu, suka membantu teman, bahkan bantuan yang sangat luar biasa.

“Anggi ingin membantu Kaka. Boleh ya Pa?", Tanya Anggi kepada ayahnya $\cdots$ 
"Apakah kira-kira Papa bersedia memberikan bea siswa kepada Kaka?", Tanya Anggi.

Pada kutipan lain digambarkan seperti berikut ini.

"Dua minggu lagi, Kaka ulang tahun. Anggi ingin ngasih hadiah yang bermanfaat buat Kaka", Anggi berhenti sejenak, menunggu reaksi ayah ibunya.

"Anggi mau ngasih motor hi..hi..hi.." agak malu-malu Anggi bilag ke ayah ibunya (Sardjono, 2019).

Sementara itu pada bagian epilog (halaman 283-291) digambarkan kebaikan hati Anggi, Olive dan Gendis membangun rumah Kaka dengan menggandeng stasiun TV dalam acara "Rumah Sehat".

Kebaikan Anggi juga diperlihatkan kepada tokoh Santi. Dikisahkan ibu Santi yang membuka kantin di area kampus tempat Santi berkuliah. Anggi, Olive, dan Gendis selalu memasukkan uang yang lebih ke laci penyimpanan uang. Santi tidak merasa tersinggung, karena begitulah teman-temannya menunjukkan persahabatannya.

Tampaknya ke-6 tokoh ini memang menjadi corong untuk menyampaikanmetode penelitian hukum itu seperti apa. Diskusi-diskusi yang dilakukan oleh tokoh-tokoh itu dalam rangka membangun alur cerira sekaligus tahapan-tahapan dalam penelitian hukum.Secara fisik buku ini seandainya tidak ditulis dalam subjudul Sebuah Novel Tentang Metode Penelitian Hukum, maka akan dikategorikan sebagai buku teks. Lebih-lebih kalau diperhatikan pada daftar isi, kurang mencerminkan sebuah novel (pembagian Bab: lihat analisis aspek sintaksis).

\section{c. Aspek Verbal}

Pada aspek verbal yang akan dibahas adalah gaya penyampaian. Hal ini terkait erat dengan penggunaan bahasa. Riset Hukum yang ditulis Agus Sardjonomenggunakan bahasa yang mudah dipahami, baik penyampaian secara analitik maupun dramatik. Kutipan berikut menunjukan contoh corak analitik.

"Hujan belum uga berhenti. Meski hari mulai malam, beberapa mahasiswa masih berkelompok di sana-sini" (Sardjono, 2019) 
"Anggi adalah anak satu-satunya dari pasangan Hardi dan Woro. Hardi seorang pengusaha sukses... Dulu Hardi dan Woro sama-sama kulaih di UI. Hardi Fakultas Teknik, Woro di Fakultas Sastra, sekarang Fakultas Ilmu Budaya (Sardjono, 2019).

Kutipan tersebut merupakan bentuk gaya penyampaian secara analitik, maksudnya menjabarkan situasi dan kondisi secara runtut dalam bentuk pemaparan langsung. Namun, novel ini juga menggunakan gaya dramatik seperti kutipan berikut.

"Di sinilah menariknya teori hukum", jawab Kaka langsung pada pokok persoalan, "Pembahasan mengenai teori-teori hukum yang beragam dan berbeda-beda itulah esensi hukum..."(Sardjono, 2019).

"Hans Kelsen pada bagian awal tulisannya 14..."(Sardjono, 2019).

Kutipan tersebut menunjukkan gaya dramatik, yakni dalam wujud dialog antartokoh, yakni Kaka, Anggi, dan Santi

Contoh dramatik yang lain seperti berikut ini.

“Waduuuh... ngeri gue, bau-bau narkoba. Apalagi kalau nanti harus riset di penjarapenjara. Takut ah".kata Anggi

"Guys... Olive menyela, "Gue ada berita bagus niih buat Kaka"

“Apaan itu Liv?", Kaka antusia

"Lu mau beasiswa gak" Tanya Olive (Sardjono, 2019).

Gaya yang digunakan dalam kutipan tersebut adalah logat Betawi/Jakarta. Gaya ini diasumsikan sebagai gaya anak muda yang "ngetrend", terlebih yang bedialog tersebut adalah mahasiswa UI. Para tokoh memang cenderung kalau dalam situasi informal (santai) memang cenderung menggunakan dialog dengan logat Betawi.

\section{SIMPULAN}

Novel Riset Hukum merupakan bukti, bahwa sastra merupakan wadah yang sangat luas. Di dalam sastra dapat diisi persoalan yang bermacam-macam. Seperti: sejarah, psikologi, politik, agama, termasuk ilmu hukum yang dijabarkan dalam novel ini. Upaya Agus Sardjono untuk menjabarkan ilmu hukum melaluiranah sastra merupakan terobosan yang luar biasa. Melalui dunia sastra, ilmu hukum yang biasanya mengerutkan dahi mampu dibaca dengan lebih cair melalui diskusi antar tokoh, penggunaan bahasa yang mudah ditangkap. 


\section{DAFTAR PUSTAKA}

Hadjon dan Tatiek Sri Djatmiati, (2020). Argumentasi hukum. Yogyakarta: Universitas Gadjah Mada Press.

Marzuki, Peter Mahmud, (2005). Penelitian hukum. Jakarta: Kencana.

Culler, Jonathan.(1975). Structuralist poetics. Ithaca NY: Cornell University Press.

Dirjen Dikti. (1982). Metodologi penelitian IB.Jakarta: Proyek Pengembangan Institusi Pendidikan Tinggi Depdikbud.

Kayam, Umar. (1982). Percabulan dalam sastra. Satyagraha Hoerip (Ed). Sejumlah Masalah Sastra. Jakarta: Sinar Harapan.

Kuntowijoyo. (1984). Penokohan dan perwatakan dalam sastra Indonesia. dalam Sastra Budaya oleh Selo Soemardjan dkk. Jakarta: CV. Rajawali.

Sardjono, Agus (2019). Riset hukum: sebuah novel tentang metode penelitian hukum. Depok: Muai kencana PT RajaGrafindo Persada.

Susanto, Dwi (2012). Pengantar teori sastra. Yogyakarta: CAPS.

Todorov, Tzvetan. (1985). Tata sastra (terj. Okke KS Zaimar dkk). Jakarta: Penerbit Djambatan. 